\title{
Laiduntaminen lypsyrobottitilalla ja laiduntamisen kustannukset
}

Heikki Havukainen; Pekka Murtorinne; Hannu Viitala1; Pirjo Suhonen1; Risto Kauppinen

1) Savonia-ammattikorkeakoulu, PL 72, 74101 Iisalmi, etunimi.sukunimi@savonia.fi

\section{TIIVISTELMÄ}

Laidunnus lopetetaan lypsyrobottiin siirtymisen yhteydessä usein kokonaan, koska se koetaan vaikeaksi, työlääksi ja kalliiksi. Samaan aikaan elintarvikkeita jalostavat yritykset käyttävät markkinoinnissa laiduntavia eläimiä. Kuluttajille voi muodostua ristiriita, kun tuotteita mainostetaan laiduntamisella, mutta todellisuudessa eläimiä näkyy pelloilla entistä harvemmin. Laiduntamisesta on hyötyä myös lybsyrobottitiloilla. Laiduntaminen parantaa eläinten terveyttä ja sille saadaan hyvinvointitukea.

Tässä työssä selvitetään, kuinka laiduntaminen lypsyrobottitilalla toteutetaan ja mitkä ovat laiduntamisen kustannukset. Lypsyrobottiin siirryttäessä laiduntaminen usein lopetetaan. Syitä tähän on muun muassa lypsyrobottitilan laiduntamiseen liittyvän tutkimuksen puute.

Työn tausta-aineistona on Savonia-ammattikorkeakoulussa tehty esiselvitystyö 60 lypsylehmän lypsyasema- ja lypsyrobottipihaton laiduntamisen eroista. Lypsyrobottitilan laiduntamisen tutkimiseen tarvittu aineisto kerättiin haastattelemalla kuutta laiduntavaa lypsyrobottitilaa Pohjois-Pohjanmaalla, Pohjois-Savossa ja Keski-Suomessa. Haastattelut tallennettiin sanelulaitteella, josta ne litteroitiin. Litteroidusta aineistosta muodostettiin laiduntamismallit.

Tutkimustiloilla kaikki yli kuusikuukautiset naudat laidunnetaan. Kaikki eläimet saavat laiduntaa vapaasti ympäri vuorokauden. Hiehot ja umpilehmät saavat laitumelta kaiken rehustuksensa. Lypsylehmillä laitumen osuus rehustuksesta on pieni, tutkimustiloilla maksimissaan $25 \%$. Laidunta tiloilla on käytössä lypsyssä oleville lehmille yhteensä keskimäärin 4,7 ha, mikä tarkoittaa keskimäärin 0,075 ha/lehmä. Lehmät pääsevät ulos toukokuussa ja viimeistään syyskuussa laiduntaminen loppuu. Laiduntaminen vähentää lehmien lypsykertoja keskimäärin 0,05 vuorokaudessa/lehmä. Laiduntaminen lisää kustannuksia aitausmateriaalien, juomaveden järjestämisen sekä eläinten siirtelyyn kuluvan työajan lisääntymisen vuoksi. Toisaalta navettatyöajan väheneminen tuo saman verran säästöjä joten laiduntamisen vuoksi työ, tai materiaalikustannuksia ei tule lisää, vaan työnkuva muuttuu erilaiseksi. Kun verrataan lypsykertojen määrän vähenemisestä johtuva maidontuotannon alenemaa eläinten hyvinvointituen määrään, voidaan tehdä päätelmiä laiduntamisen kannattavuudesta. Laskelmien mukaan laiduntaminen kannattaa tutkimustiloilla.

Laiduntamisen suunnittelu kannattaa aloittaa jo uutta navettaa rakennettaessa. Navettaa suunniteltaessa on tärkeää sijoittaa navetta siten, että saatavilla on riittävä määrä peltoa. Näköyhteys navetalta toisiin eläimiin ja laitumelta navettaan on hyvä tapa parantaa lehmien kiertoa navetalle. Laitumelle pääsyä ei pitäisi joutua katkaisemaan esimerkiksi lietteen ajon tai rehun teon takia. Jos laiduntamisella ei tavoitella ruokinnallista merkitystä vaan pyritään parantamaan lehmien terveyttä ja hyvinvointia, laitumelle ei tarvitse tehdä suuria panostuksia.

Asiasanat: Laiduntaminen, Lypsyrobotti, Kustannukset 


\section{Johdanto}

Lypsyrobotit ovat yleistyneet viime aikoina huimasti. Monesti laidunnus jätetään lypsyrobottiin siirtymisen yhteydessä pois kuviosta, sillä se koetaan vaikeaksi, työlääksi ja kalliiksi toteuttaa. Toisaalta samaan aikaan elintarvikkeita jalostavat yritykset ovat pyrkineet brändäämään elintarvikkeensa, luonnon ja laiduntamisen avulla. Tästä muodostuu tulevaisuudessa ristiriita, jos tuotteita mainostetaan laidunnuksella, mutta oikeasti eläimiä ei pelloilla näy. Viime aikoina yleisessä keskustelussa on ollut esillä myös tulevassa eläinsuojelulaissa oleva mahdollinen uusien parsinavetoiden rakentamisen kieltäminen. Tämä saattaa osaltaan myös vähentää laiduntamista, sillä juuri parsinavetoissa olevat karjat laiduntavat.

Suomalaisista lypsykarjatiloista 87 prosentilla laidunnetaan. Ruotsissa kaikki tilat laiduntavat navettatyypistä riippumatta ja Tanskassa noin kolmannes lehmistä laiduntaa. Suomessa on 60 päivän jaloitteluvelvoite parsinavetoille ja Ruotsissa laiduntaminen on pakollista. (Sairanen 2012). On kuitenkin otettava huomioon, että keskilehmäluku Suomessa on noin 30 yksilöä ja suurimmat tilat eivät laidunna. Laiduntavien eläinten osuus kaikista maamme lehmistä on siis huomattavasti $87 \%$ :a pienempi.

Lypsyrobottikarjan laiduntamisesta on saatavilla hyvin vähän tutkimustietoa. Tutkimuksen keskeinen ongelma oli: Kuinka laiduntaminen on teknisesti mahdollista toteuttaa. Selvitettiin esimerkiksi kuinka vapaa pääsy laitumelle toimii vai onko laidunnusportti tarpeellinen? Toinen tutkimuskysymys oli: mitä lisäkustannuksia laiduntamisesta aiheutuu tilalle ja saako siitä vastavuoroisesti korvausta. Lopputulemana tutkimuksessa vertailtiin laiduntamisesta syntyviä lisäkustannuksia eläintenhyvinvointituen määrään. Tutkimuksella pyrittiin tuomaan uusia ratkaisuja ja vaihtoehtoja jo laiduntaville lypsyrobottikarjoille. Toisaalta haluttiin myös herättää elintarvikeketjun toimijat todellisuuteen, jossa laitumella laiduntava lehmä ei ole itsestäänselvyys. Toivottavaa olisi, että työn seurauksena viriäisi yleinen keskustelu laiduntamisesta lypsykarjatiloilla.

\section{Aineisto ja menetelmät}

Tutkimusaineisto kerättiin haastattelemalla karjaansa laiduntavia lypsykarjatiloja. Teemahaastattelu sopi työhön, sillä se antaa sopivasti liikkumavaraa itse haastattelutilanteessa. Toisaalta teemahaastattelu on kuitenkin tarpeeksi suunniteltu ja pysyy asiassa, koska tietty runko haastattelulle on tehty etukäteen. Teemahaastattelun tavoite ei ole edetä kaavamaisesti kysymysten mukaan, vaan ennemminkin haastateltavan vastausten mukaan.

Haastateltavat tilat valittiin yhteystiedoista, joita saatiin ProAgria Oulun ja ProAgria Pohjois-Savon kautta sekä Savonia AMK agrologiopiskelijoiden sähköpostikyselyn avulla. Kyseisten lähteiden kautta saatiin alustavasti 13 laiduntavan automaattilypsytilan yhteystiedot. Kaikille tiloille soitettiin ja kysyttiin pitääkö tieto laiduntamisesta paikkansa. Jos saatiin kuulla, että tila laiduntaa lypsylehmiä kysyttiin yrittäjiltä lisää laiduntamisesta ja sen toteutuksesta, jotta saatiin karkea käsitys kuinka mikäkin tila on laiduntamisen järjestänyt. Puhelinkeskustelun yhteydessä kysyttiin laiduntavilta tiloilta myös kiinnostusta osallistua tutkimukseen haastateltavana. Ensimmäisen soittokierroksen jälkeen huomattiin, että moni toteuttaa laiduntamisen hyvin samaan tapaan. Kaikki tilat eivät vastanneet puheluihin.

Haastateltaviksi valittiin mahdollisimman erilaisia laiduntamisratkaisuja toteuttavia tiloja. Haastatteluja tehtiin Pohjois-Pohjanmaalla, Pohjois-Savossa ja Keski-Suomessa yhteensä kuusi kappaletta. Tilojen karjakoot on esitetty kuviossa 1. Haastattelut toteutettiin 8-14.1.2014. Aika oli hyvä haastattelujen toteuttamiseen, sillä tiloilla ei ollut kyseiseen aikaan muita kiireitä. Tutkimuksen kannalta oli hyvä että kaikki haastattelut saatiin tehtyä viikon sisään. Näin haastattelutilanteet olivat mahdollisimman yhtäläiset. Kysymysrunko lähetettiin yrittäjille päivää tai pari ennen varsinaista haastattelua, jotta haastateltavat voivat valmistautua eri aihealueisiin. 


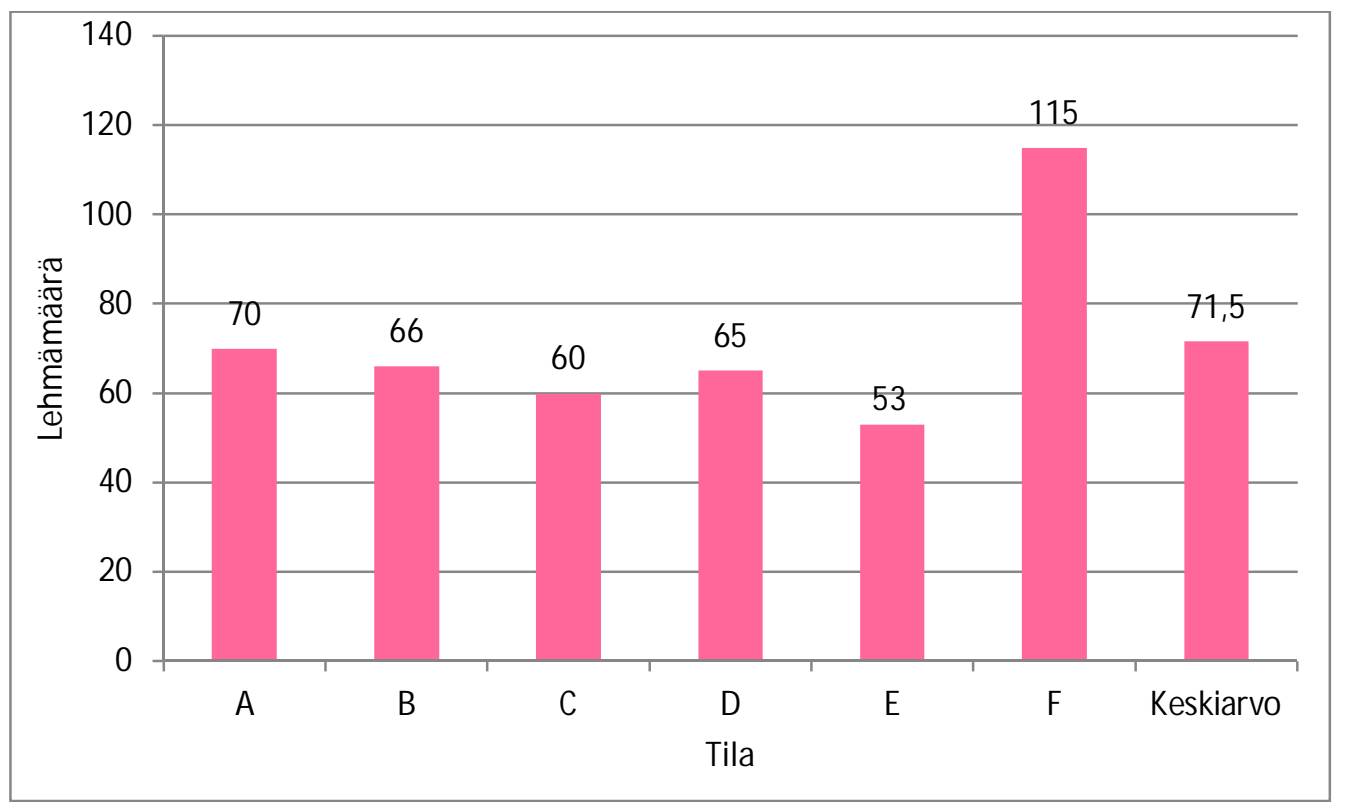

Kuvio 1: Haastateltujen tilojen lehmämäärä

\section{Tulokset}

Laitumet on valittu usein näköyhteyden ja etäisyyden mukaan. Näköyhteys navettaan ei ole täysin välttämätön, mutta se parantaa huomattavasti lehmien liikkumista laitumelta navetalle. Samanlainen vaikutus on myös näköyhteydellä muihin lehmiin. Laidunlohkoa valittaessa etäisyytenä laitumelta navetan oville voidaan pitää 300 metriä, jonka jälkeen lehmien liike laitumelta takaisin navetalle alkaa heikentyä. Ehdottomana takarajana voitaneen pitää 500 metriä.

Keskimäärin laidunta oli varattu 0,075 hehtaaria lehmää kohti. Suurin laidun pinta-ala oli 0,133 hehtaaria lehmää kohti ja pienin 0,013. Suurimmalla pinta-alalla olevalla tilalla, lehmiä oli 60 ja pienimmällä 115. Pienimmällä pinta-alalla varustettu tila koki laiduntamisen enemmän jaloitteluna. Suurimman pinta-alan tila sai laitumelta ruokinnallista hyötyä ja se oli huomattu säilörehu menekin pienenemisenä laidunkauden aikana. Pienimmällä pinta-alalla laiduntava tila totesi laitumen kestävän lehmien ulkoilemisen ja ruokinnallisen merkityksen olevan merkityksetön.

Laidunkaudella lehmien ruokinta ei muuttunut millään tavoin verrattuna sisäkauden ruokintaan. Säilörehua tai seosrehua pidettiin aina saatavilla reilusti, jolloin lehmien energian ja valkuaisen tarve täyttyy laitumen satotasosta huolimatta. Laidunkaudella säilörehun menekki voi pienentyä, mikäli laitumet ovat hyvässä kasvukunnossa ja pinta-alaa on ainakin 0,075 hehtaaria per lehmä. Tällöin lehmät saavat laitumelta osan tarvitsemastaan karkea rehusta. Kaiken karkea rehun saamiseen laitumesta vaaditaan keskimäärin 0,31 hehtaaria (Virkajärvi \& Sairanen 2002). Laidunkauden loppua kohti siirryttäessä laitumen merkitys pienenee ja säilörehun kulutus palaa talvikauden aikaan. Säilörehun kulutusta täytyy seurata päivittäin ja jakaa sen mukaan säilörehu ruokintapöydälle. Tilan suorittaessa lehmien laidunnusta vain päivällä on pyrkimyksenä ollut jakaa säilörehua pöydälle vasta lehmien sisälle ottamisen yhteydessä. Tämä lisää lehmien halua palata sisälle.

Laiduntamista ja sen toteutusta olisi hyvä miettiä jo navetan suunnitteluvaiheessa asemakaava tasolla. Tärkeintä laiduntamisen onnistumisen kannalta ovat tietysti laitumet. Lypsylehmien laidunten pitää olla navetan välittömässä läheisyydessä ja niille pitää olla vapaa kulkumahdollisuus. Navetta pitäisi siis sijoittaa laitumien yhteyteen. Suunnitteluvaiheessa kannattaa miettiä muiden tarvittavien rakennusten, kuten lantaloiden, laakasiilojen tai konehallin sijainti ja kulkuyhteydet niin, että laiduntaminen ei haittaisi tilan töitä tai hankaloita liikennettä navetan ympärillä. Sesonkiaikoina kuten lannanajon tai rehuteon yhteydessä 
lehmien kulkureitti laitumelle voidaan siirtää, laidunta voidaan pienentää tai lehmiä pitää sisällä, eikä se vaadi vielä suurta vaivaa. Jos laidunaidat ovat päivittäisen liikenteen edessä, ei tilan liikennettä ole suunniteltu järkevästi. Uuden navetan suunnittelu vaiheessa on siis tärkeään suunnitella asemakaava siten, että laiduntaminen onnistuu mahdollisimman vähällä vaivalla.

\section{Tÿ̈аika}

Laiduntamiseen kuluvaa työaikaa on hankala erotella omaksi kokonaisuudeksi varsinkin robottilypsyn yhteydessä. Aitojen laittamisen keväällä, hoitamisen kesällä ja purkamisen syksyllä voi melko helposti erotella ja todeta kyseisiin toimenpiteisiin kuluneen ajan. Se on helppoa, koska se on selvä laiduntamisesta seuraava lisätyö, ja se ei liity normaaliin navettatyöhön. Työntekijä pystyy siis sanomaan milloin kyseinen työ alkoi ja milloin se loppui. Eläinten siirroissa ryhmästä toiseen esimerkiksi ummessa olevan, mutta kohta poikivan lehmän siirto ummessa olevien laidunryhmästä lypsävien ryhmään, kuluva aika on jo vaikeampi erotella normaaliin sisäruokintakaudella kuluvaan aikaan ja laiduntamisen lisäämään aikaan. Hankalinta on kuitenkin päivittäisten navettatöiden työajan erotteleminen sisäruokintakaudella normaalisti tehtävään työhön ja laiduntamisesta seuraavaan työhön.

Työmäärä lisääntyy laiduntamisen vuoksi aitojen teon, hoidon ja purkamisen seurauksena. Kyseisten töiden työmäärä riippuu millaisia aitoja tehdään ja kuinka paljon. Jos lehmille aidataan yksi hehtaarin kokoinen suorakulmion muotoinen alue, ei aikaa kulu paljoa varsinkin, jos aitoja ei pureta talveksi. Toisaalta, jos lohkoja on paljon, ne ovat muodoltaan moninaisia, osa aidasta tehdään metsään ja kaikki aidat on purettu edellisen kesän jäljiltä, on työajan kulutus aivan toinen. Haastateltujen tilojen aitaustavoissa ja laitumen syöttötavoissa oli eroja, josta seurasi eroja myös aitaamiseen käytettyyn työaikaan. Työaika on selvästi pienempi, mikäli laidunlohkot ovat selkeitä esimerkiksi suorakulmaisia ja aidat tehdään kestävistä materiaaleista kerralla kunnolla, jolloin niihin voidaan luottaa useampana vuonna. Työaikaa lisäävä tekijä on aitojen purkaminen syksyisin. Keskimäärin tilat ilmoittivat aitaamiseen kuluvan 46 tuntia laidunkaudessa.

Eläinten siirtoon käytettävä työaika vaihtelee, koska tilojen toimintatavat vaihtelevat. Keskimäärin tiloilla menee eläinten siirtelyyn aikaa 96 minuuttia viikossa. Jos eläimet ovat laitumella neljä kuukautta, menee eläinten siirtelyyn aikaa laidunkaudella yhteensä keskimäärin 28,8 tuntia. Kyseistä työaikaa laskettaessa on otettu huomioon kaikkien siirrossa mukana olleiden työntekijöiden työaika. Siirtoihin kuluva aika vaihteli paljon tiloittain. Eniten ja vähiten aikaa käyttävän ero on 180 minuuttia eli kolme tuntia viikossa. Kyseinen ero muodostuu ummessa olevien lehmien ja tiineiden hiehojen laitumien sijainnista. Työaikaan vaikutti eniten eläinten sijainti suhteessa toisiin ryhmiin. Siirtoon kuluu sitä enemmän työaikaa mitä pitempiä matkoja eläimiä joudutaan liikuttelemaan ja mitä useampi henkilö työssä on mukana. Eläimiä voidaan siirtää melko nopeasti pitempiäkin matkoja, jos siirtoa varten on tehty kulkureittejä. Näin eläimet menevät nopeasti oikeaan paikkaan, eikä siirtoon tarvita montaa henkilöä.

Toinen tekijä, joka vaikuttaa kyseiseen ajan käyttöön on kuinka usein ja miten monta eläintä kerralla siirretään. Tehdäänkö siirto kootusti esimerkiksi kerran kahdessa viikossa ja siirretään kaikki eläimet, joita tarvitsee liikutella kerralla. Vai siirretäänkö eläimiä yksi kerrallaan aina, kun siihen on tarvetta. Kesän aikana laiduntavalla robottitilalla tehtäviä eläinten siirtoja ovat umpeutettujen lehmien siirto ummessa olevien ryhmään, poikivien lehmien ja hiehojen siirto lypsylehmien ryhmään, siemennettävien hiehojen sisälle ottaminen, mikäli siemennys tapahtuu sisällä, siemennettyjen hiehojen uloslasku ja eläinryhmien siirtäminen laidunlohkolta toiselle.

\section{Kustannukset}

Laiduntamisesta seuraa sekä materiaalikustannuksia että työkustannuksia. Materiaalikustannuksia ovat aitausmateriaalien kustannukset ja juomaveden järjestämisestä koituvat lisäkustannukset. Työkustannukset muodostuvat aitaamisesta, eläinten siirtelystä ja juomaveden järjestämisestä. Kustannuksia tiedusteltiin suoraan tiloilta. Laidunnusportista ja juomavedenjärjestämisestä koituvia kustannuksia piti jakaa useammalle vuodelle, sillä osa kyseisistä hankinnoista oli käytössä kauemmin kuin vuoden ja eikä niitä 
hankita joka vuosi. Näissä tilanteissa vuotuiset kustannukset laskettiin annuiteettimenetelmällä. Aitausmateriaalikustannukseen voisi laskea hieman aitojen perustamisen kustannusta. Työssä käytetyt kustannukset sekä materiaalien että työn osalta ovat vain ylläpitokustannuksia. Kun aidat on tehty ensimmäistä kertaa, on materiaaleja ja työtä kulunut enemmän ja osasta on hyötyä myöhemmin.

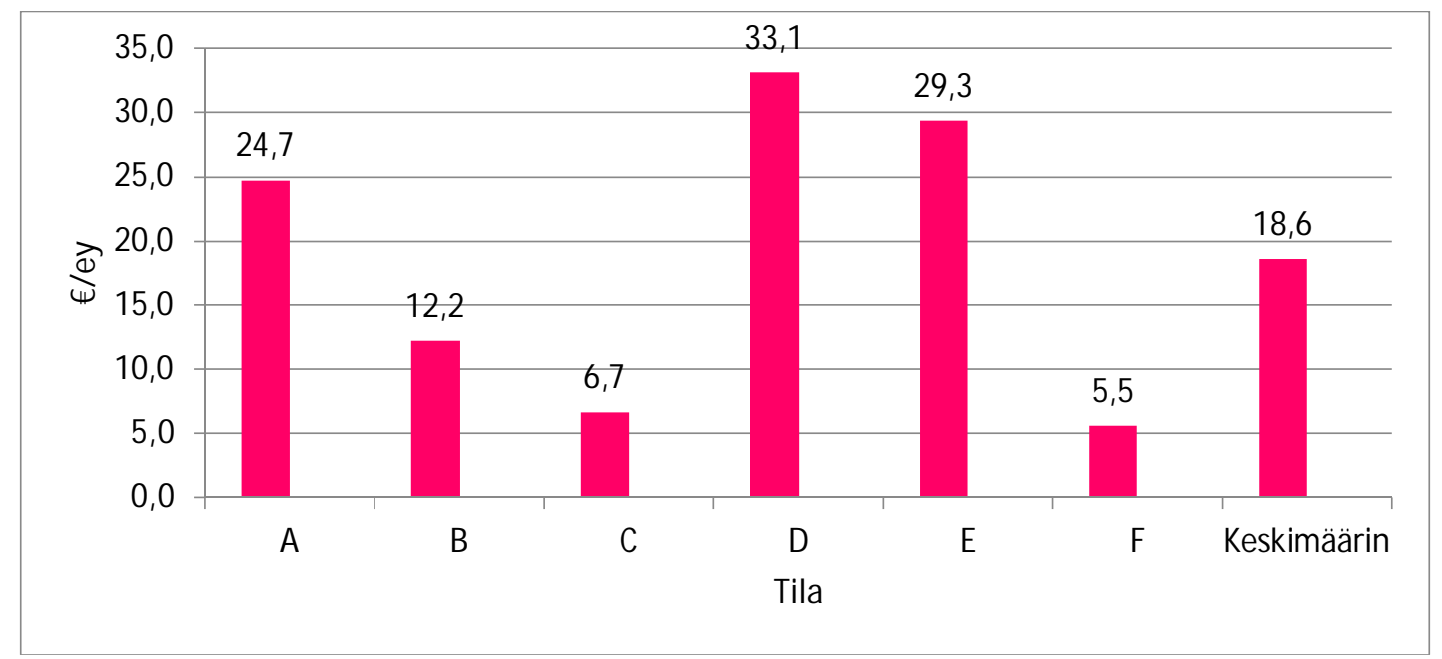

Kaavio 2: Laiduntamisesta seuraavat lisäkustannukset eläinyksikköä kohti tiloittain ja keskimäärin.

Tilakohtaisiin kustannuksiin eniten vaikuttaa käytetyn työajan määrä. Esimerkiksi tilalla D eläinten siirtelyyn kuluu aikaa 75 tuntia kesässään, kun tila B selviää 9,6 tunnilla. Ero johtuu pääosin laidunten sijainnista. Tilan A kustannusta nostaa laidunportti, joka on laskettu kuulu-vaksi aitausmateriaaleihin. Laidunportin poistoaikana käytettiin 15 vuotta ja korkoprosenttina $5 \%$. Tarkemmin tilakohtaisiin kustannuksiin voi tutustua laidunnuksen toteutus ja työaika osioista löytyvien taulukoiden avulla. Aitausmateriaalien kustannukset olivat keskimäärin $469 € /$ vuosi. Keskimäärin laiduntamisesta seuraava kustannus haastattelutiloilla on 18,6 €/eläinyksikkö (Kaavio 2).

Maitomäärä väheni laidunkaudessa keskimäärin 4087 litraa/tila haastattelutiloilla. Jos maidon hintana käytetään $0,45 €$, lypsylehmää kohti tämä tarkoittaa $25,7 €$ laidunkaudessa. Eläinyksikköä kohti tämä tarkoitta 17,4 € kustannusta. Maidontuotannon alenemasta ja laiduntamisesta seuraavista lisäkustannuksista yhteenlaskettuna saadaan laiduntamisen kokonaiskustannus. Tässä työssä tehtyjen laskelmien mukaan se on 36,0 €/eläinyksikkö.

Laiduntamisesta koituu tilalle säästöjä vähentyneen navettatyöajan seurauksena. Navettatöiden määrä väheni neljällä kuudesta tilasta laidunkaudella. Navettatyöt vähenivät keskimäärin 1,2 tuntia päivässä haastattelutiloilla. Tästä seuraa säästöä kustannuksissa. Kyseinen työajan säästö on muutettu eurouksi kaaviossa 16. Se on esitetty muodossa euroa/eläinyksikköä laidunkaudessa. Keskimäärin säästö on haastattelutilalle 23,4 €/ey/laidunkausi.

\section{Johtopäätökset}

Laiduntamisen seurauksena muuttunutta työaikaa on hankala määritellä, koska työnkuvan muuttuminen lisää toista työvaihetta, mutta vähentää työmäärää jossain toisaalla. Työssä eriteltiin aitojen tekemiseen ja hoitoon, eläinten siirtelyyn ja juomaveden järjestämiseen laitumelle kulunut työaika. Ne määriteltiin laiduntamisen seurauksena lisääntyväksi työajaksi. Mahdollisia työajan vähentymiskohteita ei määritelty erikseen, vaan se selvitettiin sisäruokinta- ja laidunkauden päivittäisten navettatöiden työajan muutoksen avulla. Tutkimuksen mukaan neljällä haastattelutiloista navettatöihin kulunut aika on lyhempi kuin sisäruokintakauden työaika. Kun laidunkauden navettatöihin lisätään myös laiduntamisesta seuraavat 
lisätyöt, on kahden tilan työaika pitempi laidunkaudella kuin sisäruokintakaudella, yhdellä tilalla työajat ovat suunnilleen samanpituiset ja kolmella tilalla laidunkauden työaika jää lyhemmäksi kuin sisäruokintakauden työaika. Keskimäärin työaika lyhenee laidunkaudella 0,6 tuntia/tila päivässä, kun huomioidaan sekä navettatyöt että laiduntamisesta seuraavat lisätyöt.

Laiduntamisesta seuraavan työajan muutokseen vaikuttaa eniten tilakohtaiset työtavat kuten kuinka aidat tehdään, kuinka, miten usein ja minne eläimiä siirretään ja miten eläinten juotto on järjestetty. Aitojen tekemisestä syntyy enemmän kuluja, kun aidat pitää tehdä kestäviksi esimerkiksi yleisen tien vuoksi. Eläinten siirrosta puolestaan syntyy kuluja, jos yksittäisiä eläimiä siirretään useasti ja matka on pitkä. Juomaveden järjestämisessä puolestaan selviää halvalla, jos eläimet voivat juoda suoraan vesistöstä tai navetalla sisältä. Navettatöiden märän muutoksen puolestaan vaikuttaa eniten kuinka eläinten ruokinta, lannanpoisto ja kuivitus tehdään. Työt helpottuvat ja työaika lyhenee monesti paljon, varsinkin, jos umpilehmien ja hiehojen hoitotyö on sisäruokin-takaudella työlästä. Näin on monesti silloin, kun kyseiset eläinryhmät pidetään vanhassa lypsylehmänavetassa.

Laiduntamisesta seuraa työnajan vähenemistä sekä kustannussäästöä peltoviljelyn puolella, sillä lannanajoa ja rehuntekoa on vähemmän. Laiduntamisesta seuraavat kustannukset muodostuvat työ-, aitamateriaali- ja juoma-veden järjestämisen materiaalikustannuksista. Kustannuksia syntyy myös maidontuotannon alenemisesta. Toisaalta navettatöiden määrän vähenemisestä seuraa työkustannusten pieneneminen. Kustannuksia kompensoi eläinten hyvinvointituki. Moni viljelijä on sitoutunut hyvinvointitukeen vuonna 2012. Tällöin hyvinvointituen laiduntamiseen liittyvät korvaussummat olivat joko $29 €, 35 €$ tai $57 €$ riippuen kuinka pitkään eläimiä laiduntaa.

Laiduntamisesta syntyvät kustannukset ovat tämän työn mukaan 18,6 €/ey. Ne kumoutuvat haastattelutiloilla vähenneenä työmääränä navetalla, mikä on eläinyksikkö kohden 23,4€. Edellä mainittujen lukemien mukaan tila jäisi laiduntamisesta näiden laskennallisten kustannusten ja säästöjen jälkeen 4,8 €/ey voitolle. Mutta, koska maatalousyrittäjän tuntipalkka ei aina yllä aivan $15,9 € / \mathrm{h}$ vaatimukseen, kustannusten ja säästöjen erotus kapenee. Esimerkiksi 8,6 €/tuntipalkalla laiduntamisesta syntyvät kustannukset ja säästöt ovat samansuuruiset. Kun vielä huomioidaan, että laiduntamisen kustannukseen ei ole huomioitu aitojen perustamiskustannusta ensimmäiseltä vuodelta, voidaan sanoa, että laiduntamisen kustannukset ja säästöt kumoavat toisensa.

Eläinten lypsyllä käyntitiheys näyttääkin olevan laiduntamisen kannattavuuden kulma-kivi lypsyrobottitilalla. Maidontuotannon alenemaan osoittavan laskurin mukaan haastattelutilojen keskimääräisillä arvoilla yhden kymmenyksen vähennys päivittäisissä lypsykerroissa lehmää kohti tarkoittaa 52,6 €/lehmä menetystä laidunkauden aikana maitotuloissa. Kyseinen luku puolestaan tarkoittaa keskimääräisellä eläinyksikkömäärällä 35,5€ menetystä eläinyksikköä kohti. Maidontuotannon alenemaa ja sen kustannusta voi verrata hyvinvointituen määrään mistä voi päätellä laiduntamisen kannattavuutta. Haastattelu tilojen keskimääräisillä arvoilla laiduntaminen näyttää kannatta-valta sillä maidontuotannon alenema aiheuttama kustannus on laskurin mukaan 17,4€/ey ja eläinten hyvinvointituen korvaus 75 päivän laiduntamisesta $29 € /$ ey.

Haastattelutilat kokivat laiduntamisen kannattavaksi ja toivoivat, että useammatkin tilat alkaisivat laiduntaa. Enimmäkseen he kokivat että laiduntamattomuus on asenteista kiinni. He kokivat, että mahdollinen lisätuki rakentamiseen, tuotteen hintaan tai hyvin-vointiin voisi olla vaihtoehto lisätä laiduntamista. Laskettaessa litraa kohti laidunkaudella lypsykertojen määrän vähenemisestä aiheutuva menetys, tulee tulokseksi noin $0,009 € /$ litra. Laiduntava lypsyrobottitila tarvitsi siis vajaan yhden sentin lisähinnan tulon menetyksen kattamiseksi. Meijerin antaman tuen vaihtoehdoksi voisi nostaa rakentamisen tukemisen. Rakentamisen tukeminen vaikuttaa laiduntamiseen hitaasti ja pitkällä aika jänteellä. Tämä kuitenkin vähentäisi sellaisten navetoiden rakentamista, joiden pelkkä sijainti tekee laiduntamisesta mahdotonta. Ajan ja rakennemuutoksen kourissa kouristeleva karjatalous siirtyisi hiljalleen takaisin laiduntavien karjatilojen maaseutuun.

Kuinka suuri on eläinterveyden mahdollinen vaikutus kustannuksiin jää tämän tutkimuksen osalta avoimeksi kysymykseksi. Haastattelujen perusteella yrittäjät olivat vahvasti sitä mieltä, että laiduntamisen vaikutus eläinterveyteen on joka tapauksessa positiivinen. Jos laiduntamisella voidaan säästyä eläinlääkärinkäynniltä, säästää keskimääräinen haastattelutila yli yhden euron eläinyksikköä kohti, kun 
mietitään että eläinlääkärikäynti lääkkeineen maksaa lähes aina yli sata euroa ja haastattelutilojen keskimääräinen eläinyksikkömäärä on noin 105. Samalla tapaa laskettuna kahden siemennyskerran säästö laidunkaudessa tekee kokonaisuudessaan säästöä yli yhden euron jokaista karjan eläinyksikköä kohti.

Työn mittaan nousi esille tarve lisätutkimukselle, jossa tutkittaisiin robottilypsytilojen lehmäkohtaisten lypsykertojen päivittäistä muutosta laidunkauden ja sisäruokintakauden välillä. Samassa pitäisi yrittää osoittaa millainen vaikutus lypsykertojen määrän muutoksella on maitotuotokseen. Tutkimuksessa olisi hyvä vertailla sekä laiduntavia että laiduntamattomia robottilypsytiloja. Samalla kannattaa tutkia myös vaikuttaako laitumen määrä lypsykertojen määrään. Toisin sanoen käyvätkö lehmät vähemmän lypsyllä, jos laitumella on enemmän syömistä. Lisätutkimusta kaipaava kysymys on myös kuinka laiduntaminen vaikuttaa eläinterveyteen ja varsinkin se mitä se merkitsee euroina.

\section{Kirjallisuus}

Sairanen A. 2012. Onnistunut laiduntaminen. ProAgria Oulu [viitattu 27.11.2013]. Saatavissa : http://www.proagriaoulu.fi/files/maitomanagement/onnistunut_laiduntaminen_2012.pdf

Virkajärvi, P. \& Sairanen, A. 2002. Laidunalan mitoitus. Teoksessa Puurunen, T \& Teräväinen, .(toim.). Laiduntaminen kannattaa. Jyväskylä: Gummerus Kirjapaino Oy, 54-62 